\title{
STUDI LITERATUR PENDEKATAN QUR'ANIC TENTANG KARAKTER KETELADANAN BAGI GURU MI
}

\author{
Oleh: \\ Atikah Syamsi, M.Pd.I* \\ *Dosen Jurusan PGMI FITK IAIN Syekh Nurjati Cirebon \\ Email:atikah_1384@yahoo.co.id
}

\begin{abstract}
ABSTRAK
Semakin maraknya dunia pendidikan saat ini mengharuskan adanya peningkatan dalam alat-alat pendidikan baik itu bagi pengajar juga dalam fasilitas dan materinya. Selain peserta didik harus mempunyai persyaratan yang telah disebutkan, pendidik pun harus mempunyai SDM yang berkualitas, metode pengajaran yang tepat juga pendekatan yang sesuai dan kondisional disamping fasilitas yang memadai dan menunjang, semua hal ini merupakan penunjang dalam keberhasilan proses belajar mengajar bagi siswa.

Adapun tafsir tematik yang diusung pada satu ayat al-Ahzab ini adalah membahas satu judul tertentu secara mendalam dan tuntas, sehingga tujuan dari tafsir tematik ini tercapai, adapun tujuannya ialah untuk menyelesaikan permasalahan yang diangkat secara tuntas sehingga diperoleh suatu kesimpulan yang dapat dijadikan pegangan, baik bagi mufassir sendiri maupun kalangan awam. Dalam kajian surat al-ahzab ayat 2 ini terdapat salah satu bentuk metode pendekatan yang dibutuhkan oleh peserta didik yang harus dilakukan oleh pendidik yakni terkait dengan karakter keteladanan yang harus dicontohkan dan ditampilkan oleh seorang pendidik agar proses belajar dapat tercapai dengan optimal. Sebab pendidikan Islam dalam pelaksanaannya membutuhkan metode yang tepat untuk menghantarkan kegiatan pendidikannya kearah tujuan yang dicita-citakan, bagaimanapun baik dan sempurnanya suatu konsep pendidikan, ia tidak akan berarti apapun manakala tidak mempunyai metode atau cara yang tepat dalam mentransformasikannya kepada peserta didik.
\end{abstract}

Keyword : Tafsir Tematik, Karakter, Keteladanan

\section{A. PENDAHULUAN}

Sejarah mencatat bahwa pembacaan terhadap teks al-Qur'an telah dilakukan sejak pertama kali diturunkan, dengan keberagaman pendekatan dan metode interpretasinya. Ada yang menggunakan tafsir, takwil ataupun penerjemahan langsung terhadap teks al-Qur'an, namun kesemuanya itu 
merupakan wilayah hermeneutika yang sangat terbuka bagi setiap usaha pembaharuan. Selanjutnya dalam penulisan ini, penulis menguraikan sebuah metode "tafsir tematik" terhadap sebuah teks ayat Qur'an yang berkaitan dengan sebuah metode pembelajaran, dan bukannya penafsiran terhadap pemikiran salah satu mufassir, karena keterbatasan para mufassir yang terkait dengan tema pendidikan yang dari semula diusung. Oleh karena itu rumusan masalah pada penulisan ini ialah pada metode penafsiran satu ayat tentang pendidikan yang diperoleh dari Indek Al-Qur'an serta relevansinya terhadap dunia pendidikan. Dengan harapan semoga dapat bermanfaat bagi kita semua dan dapat memberikan pengetahuan baru yang mampu meningkatkan kualitas diri kita.

\section{B. PEMBAHASAN}

Tafsir Tematik Ayat Al-Qur'an Tentang Keteladanan (Ash-Shiddiqi, 1971 : 782)

Q.S al-Ahzab: 2

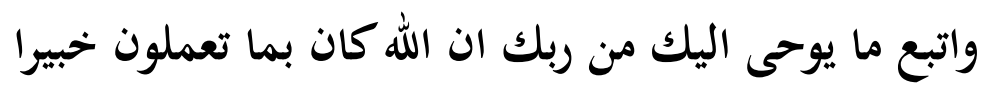

"Dan ikutilah apa yang diwahyukan tuhanmu kepadamu, sesungguhnya Allah adalah Maha Mengetahui apa yang kalian kerjakan"

Tafsir Mufrodat (al-Baidlowi, 1988: 238)

$$
\text { واتبع }
$$


Kata merupakan seruan untuk mengikuti suatu petunjuk, yang kemudian diberitakan dalam kata berikutnya yaitu ما يوحى اليك dari apa yang diwahyukan kepadamu, katika kita sampai pada kata ini maka pikiran kita tertuju pada apa yang diwahyukan itu adalah berupa ayat-ayat kauniyah (alam semesta) dan ayat-ayat Qauliyah (al-Qur'an). Adapaun alasan mengapa Allah memerintahkan untuk mengikuti atau mencontoh disampaikan pada kata berikutnya ان الله كان بما تعملون yang bermakna Allah mengetahui apa yang telah dilakukan dan akan dilakukan oleh hambanya dalam segala urusannya.

Analisa Nahwu dan Balaghoh (as-Syaikholy, $2001: 810$ )

$$
\begin{aligned}
& \text { واتبع : حرف العطف اي عطف على ما تقدم من قبيل عطف العام على الخاص } \\
& \text { و فيه دليل على ترك اتباع الآراء مع وجود النص. والخطاب له و لأمته } \\
& \text { ما يوحى : إسم موصول مبني على السكون في محل نصب مفعول به (يوحي) فعل } \\
& \text { مضارع مبني للمجهول مرفوع با الضمة المقدرة. والجملة الفعلية "يوحى } \\
& \text { إليك" صلة الموصول لا محل له من الإعراب } \\
& \text { إليك : حرف الجار والضمير ضمير متصل } \\
& \text { : حرف الجار مبني على السكون : } \\
& \text { ربّك بحرور بحرف الجار والكاف ضمير متصل مبني على الفتح في محل جر }
\end{aligned}
$$

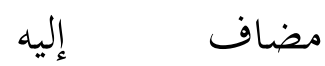

$$
\begin{aligned}
& \text { إن : رف نصب و توكيد مبني على الفتح تنصب الإسم و ترفع الخبر } \\
& \text { الله لفظ الجلالة منصوب و علامة نصبه فتحة ظاهرة في أخره } \\
& \text { كان فعل ماض مبني على الفتح في محل رفع خبر إن } \\
& \text { بما تعملون : قيل يعملون" بياء الغيبة على أن الضمير للكفرة و المنافقون. و قيل : } \\
& \text { الخطاب للرسول صلعم والجمع للتعظيم }
\end{aligned}
$$




\section{خبيرا خبر كان منصوب و علامة نصبه فتحة ظاهرة في أخره لأنه اسم المفرد}

Melihat ayat diawali dengan huruf 'athaf yang 'athaf kepada makna yang terlihat pada syarah, bahwa ini 'athaf kepada kata sebelumnya yang menunjukkan adanya penggunaan kalimat kabar di tempat kalimat perintah untuk memberi pengertian tentang kewajiban mentaati perintah itu. (al-Khattan, 2001 : 294) Sementara athaf sendiri terbagi menjadi tiga macam yaitu : 'athaf kepada lafadz, 'athaf kepada mahall (kedudukan kata) dan 'athaf kepada makna. Kemudian terkait dengan khitâb (seruan), hal ini ditujukan kepada Nabi Muhammad dan kepada umatnya, dan bukan hanya khusus kepada Nabi Muhammad semata. (alKhattan, $2001: 322$ )

Adapun analisa berikutnya mengenai lafadz kâna, dimana lafadz ini seringkali digunakan berkenaan dengan Zat Allah dan sifat-sifat-Nya seperti pada ayat ini yang menunjukkan bahwa Allah mempunyai sifat Maha mengetahui apa yang dikerjakan hambanya. Namun menurut Abu Bakar ar-Razi ia mendefinisikan penggunaan lafadz kâna dalam lima macam yaitu : 1) dalam makna azali dan abadi, seperti pada pembahasan ayat diatas, 2) dengan makna terputus (terhenti), 3) dengan makna masa sekarang, 4) dengan makna masa akan datang, 5) dengan makna sâra (menjadi). (al-Khattan, 2001 : 298)

Selanjutnya kata bimâ ta'malun diatas bermakna bahwa Allah maha mengetahui maha teliti terhadap setiap hambanya termasuk pada orang-orang kafir serta orang-orang munafik yang cenderung menutupi maksud buruknya dengan sikap yang baik, namun Allah maha tahu, dan lafadz ini dikhitabkan (diserukan) kepada Nabi serta umatnya yang begitu menghormatinya.

Kata disini berarti perintah untuk berpegang teguh pada apa yang telah disyariatkan dalam al-Qur'an. Apapun itu bentuknya, sebab itu merupakan jalan keberuntungan. (al-Jazaini, 1994 : 239)

Kata menurut Abu 'Ali, mempunyai arti yang lebih luas lagi, disamping perintah untuk mengikuti apa yang telah disyariatkan oleh al-Qur'an, ia memberikan penafsiran pada kata ini dengan pengamalan secara kontinyu serta 
penyampaian kepada orang lain (al-Fadl, 1994 : 105). Dengan demikian kata tidak hanya memiliki arti sekedar mengikuti, tetapi juga mengandung pengertian bagaimana kita bisa istiqomah dalam menjalankan apa yang telah disyariatkan oleh al-Qur'an. Jika kita sudah dapat menerapkan apa yang ada dalam al-Qur'an sebagai pedoman hidup untuk pribadi kita, maka selanjutnya yang menjadi kewajiban kita adalah penyampaian kepada orang lain.

Kata يوحى yaitu informasi yang disampaikan secara halus dan rahasia. Pengertian kebahasaan itu menjelaskan adanya hubungan yang demikian mesra antar subyek dan obyek sehingga pembicaraan disampaikan dengan lemah lembut dan dirahasiakan, tentu saja perahasiaan itu tidak dimaksudkan agar kandungan wahyu dirahasiakan oleh Nabi Saw. Karena beliau ditugaskan untuk menyampaikan kepada umat manusia apa yang beliau terima. Ini hanya mengesankan adanya hubungan khusus antara lain bahwa yang diberi wahyu itulah yang secara khusus menjadi perantara Allah menyampaikan pesan-pesanNya kepada umat manusia. (Shihab, 2002 : 217)

Penggunaan bentuk Mudlori' pada kata يوحى mengesankan adanya wahyu yang akan datang, dan itu hendaknya menjadi perhatian Nabi agar benarbenar beliau ikuti.

\section{Asbabun Nuzul Ayat}

Sebagian besar Qur'an pada mulanya diturunkan untuk tujuan memberi petunjuk kepada manusia, namun kehidupan para sahabat bersama Nabi telah menyaksikan banyak peristiwa sejarah, bahkan kadang terjadi diantara mereka peristiwa khusus yang memerlukan penjelasan hukum Allah sehingga para sahabat bertanya kepada Nabi untuk mengetahui hukum Islam mengenai hal itu, maka Qur'an turun untuk peristiwa khusus tadi atau untuk pertanyaan yang muncul tadi, yang demikian inilah yang kemudian dinamakan dengan asbabun nuzul. Adapun sebab turunnya suatu ayat terdapat dua pendapat yaitu sebab Rasul ditanya mengenai suatu hal, maka turunlah ayat Qur'an yang menerangkan hukumnya serta yang kedua adalah bila terjadi suatu peristiwa, maka turunlah ayat 
mengenai peristiwa itu seperti contohnya peristiwa tentang Abu Lahab, yang kemudian turun surat yang menggunakan nama dirinya.

Namun menurut as-Suyuti dalam al-Itqan, bahwa tidak berarti bahwa setiap orang harus mencari sebab turun setiap ayat karena tidak semua ayat alQur'an diturunkan karena timbul suatu peristiwa dan kejadian atau karena suatu pertanyaan. Tetapi ada diantara ayat Qur'an yang diturunkan sebagai permulaan tanpa sebab, serupa dengan pandangan al-Ja'bari bahwa Qur'an diturunkan dalam dua kategori yaitu yang turun tanpa sebab dan yang turun karena suatu peristiwa atau pertanyaan. (al-Khattan, $2001: 109)$

Sementara itu asbabun nuzul yang berkenaan dengan ayat 2 surat al-Ahzab ini menurut pakar tafsir Abu Hayyan menyebutkan bahwa ketika Nabi saw. tiba di Madinah beliau sangat ingin orang-orang yahudi memeluk Islam. Sebagian dari mereka kemudian berpura-pura memberi saran kepada Nabi padahal saran tersebut merugikan, maka kemudian turunlah ayat diatas. Ada juga riwayat yang menyatakan bahwa beberapa orang tokoh kaum musyrikin Mekah mendapat izin dari Nabi untuk berkunjung ke Madinah. Mereka mengusulkan agar jangan mencerca berhala-berhala mereka tetapi mengakui bahwa berhala itu dapat memberi syafaat. Usul itu sangat menjengkelkan hati Nabi sehingga yang demikian ini membuat Umar ibn Khottob berang dan meminta izin kepada Nabi untuk membunuh mereka tapi Nabi melarang, karena yang mengizinkan orangorang kafir untuk datang ke Madinah adalah Beliau sendiri dengan tujuan untuk mengajak mereka memeluk agama Islam. Sehingga kemudian turunlah ayat diatas. (Shihab, 2002 : 216) Dengan demikian maka jelaslah bahwa ayat ini memiliki asbabun nuzul dan termasuk dalam kategori yang terjadi karena suatu peristiwa yang dialami oleh Nabi beserta para sahabatnya.

\section{Metode Tafsir Tematik Ayat Al-Qur'an (Pendekatan Semantik dan Sintagmatik)}

Adalah Shahrur yang membahas tentang metodologi penafsiran al-Qur'an, yang terkenal dengan pendekatan paradigmatis dan sintagmatis. (Syamsuddin, 
2002 : 138). Analisis paradigmatic ialah suatu analisis pencarian dan pemahaman terhadap sebuah konsep (makna) suatu symbol (kata)dengan cara mengaitkannya dengan konsep-konsep dari symbol-simbol lain yang yang mendekati dan yang berlawanan. Yang menurut Sahiron pandangan Shahrur ini menyatakan bahwa di dalam bahasa arab tidak terdapat sinonim (muradif), setiap kata mempunyai kekhususan makna.

Terkait dengan pernyataan tersebut, maka penulis juga merasa bahwa metode tafsir terhadap ayat 2 dari surat al-Ahzab ini ialah menggunakan metode semantic dengan pendekatan sintagmatis, yaitu suatu analisis yang memandang bahwa makna setiap kata pasti dipengaruhi oleh hubungannya secara linear dengan kata-kata disekelilingnya. Hal ini juga bisa berpengaruh terhadap factor yang bisa menentukan makna mana yang lebih tepat dari potensi-potensi makna yang ada ialah konteks logis dalam suatu teks dimana kata itu disebutkan. (Syamsuddin, $2002: 139$ )

Analisis sintagmatis dapat disejajarkan dengan konsep yang menurut Shahrur ${ }^{1}$ sebagai konsep mawaqi'al-nujum (memperhatikan batas pemisah antar ayat) karena pada dasarnya hal itu berorientasi pada hubungan horizontal yang juga termasuk hubungan antar kata dalam satu ayat, atau hubungan satu ayat dengan ayat lain, atau hubungan satu surat dengan surat lain yang semua itu menunjukkan hubungan sintagmatis. Dalam strukturalisme, hubungan ini disebut hubungan asosiatif dimana kelompok-kelompok kata yang dibentuk berdasar kan asosiasi mental tidak hanya menyatukan istilah yang mempunyai ciri yang sama. Otak menangkap hakikat hubungan yang mengaitkan istilah-istilah tersebut dalam setiap kasus dan berdasarkan itu mencipta deret asosiatif yang sama banyaknya dengan keragaman hubungan, struktur dasar penyusun hubungan asosiatif ini adalah persatuan makna dan persatuan bentuk. (Syamsuddin, $2002: 256$ )

\footnotetext{
1 Meskipun banyak yang mengkritik Shahrur dengan metode analisis linguistiknya tersebut, misalnya Nasr Hamid Abu Zayd, lihat A. Zaki Mubarok, Pendekatan Strukturalisme Linguistik: dalam Tafsir al-Qur'an Kontemporer"ala” M. Shahrur, (Yogyakarta : Elsaq Press, 2007), hal. 284. namun Shahrur juga mempunyai kelebihan yakni masih menganggap sakralitas sebuah teks (wahyu), selain itu ia juga mampu membingkai teks tersebut dengan cara mengurai aspek semantic, filsafat bahasanya, begitu pula dengan analisis sintagmatis-paradigmatis dan historisnya.
} 
Dalam kajian tafsir ini, penulis lebih sepakat dengan pandangan Shahrur mengenai intratektualitas (tartīl), sebab dalam istilah Shahrur membaca secara tartīl adalah membaca secara tematik yaitu mengambil ayat-ayat terkait dengan satu tema tertentu lalu menghubungkan satu dengan yang lainnya untuk menangkap maksud dan pesannya secara utuh. Dan hal inilah yang disebut dengan hubungan sintagmatik dan paradigmatic (asosiatif). Namun secara kinerja penulis lebih cenderung menggunakan analisis sintagmatik yang secara definitive suatu kata yang mempunyai hubungan dengan kata-kata yang berada didepan atau dibelakangnya. (Syamsuddin, $2003: 127$ )

Adapun tafsir tematik yang diusung pada satu ayat al-Ahzab ini adalah membahas satu judul tertentu secara mendalam dan tuntas, sehingga tujuan dari tafsir tematik ini tercapai, adapun tujuannya ialah untuk menyelesaikan permasalahan yang diangkat secara tuntas sehingga diperoleh suatu kesimpulan yang dapat dijadikan pegangan, baik bagi mufassir sendiri maupun kalangan awam. (Syamsuddin, 2003 : 227) Oleh karenanya meski penulis menggunakan analisis pengetahuan modern, namun penulis juga secara konseptual tetap mengacu pada penafsiran yang dilakukan oleh ulama terdahulu

Dengan kembali melihat surat al-Ahzab ayat 2, maka kajian analisis sintagmatis berupaya untuk menjabarkan ayat sebelum dan ayat sesudahnya. Adapun ayat 1 dan 2 dari surat al-Ahzab ini ialah :

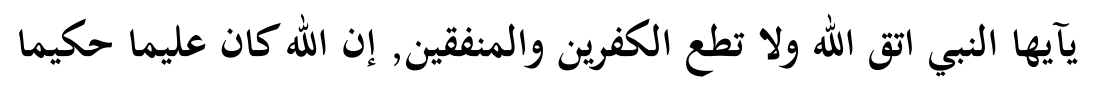

"Wahai Nabi, bertakwalah kepada Allah dan janganlah engkau menuruti (keinginan)orang-oramg kafir dan orang-orang munafik. Sesungguhnya Allah Maha Mengetahui, Maha Bijaksana"

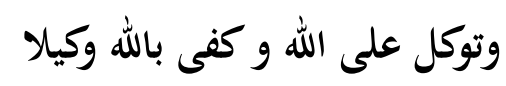

"Dan bertakwalah kepada Allah, dan cukuplah Allah sebagai Pemelihara"

Terkait dengan kedua ayat diatas, maka jika dianalisis dari aspek bahasa, maka jelas keduanya menyerukan untuk sama-sama bertakwa. Bertakwa disini mempunyai arti logis sebagai kepatuhan umat agar mematuhi segala perintahnya 
dan menjauhi segala larangannya. Terlebih lagi jika pada ayat yang pertama terdapat seruan kepada obyek khusus yaitu Nabi Muhammad. Para ulama berbeda pendapat tentang khitâb (seruan), termasuk pada khitâb yang khusus pada Nabi seperti ayat 1 diatas, apakah khitab ini mencakup seluruh umat atau tidak, Ada yang berpendapat bahwa itupun juga mencakup seluruh umat karena Rasulullah adalah panutan mereka, dan segolongan lain berpendapat tidak mencakup mereka, karena sighatnya menunjukkan kekhususan bagi Rasul. (al-Khattan, 2001 : 323)

Namun kemudian perdebatan ini bisa ditengahi dengan melihat kata setelahnya yang tidak ada khâss kepada Rasul, maka pendapat bahwa seruan ini juga ditujukan kepada umatnya menjadi lebih kuat kedudukannya. Apalagi ditambah dengan adanya asbabun nuzul yang disebabkan adanya suatu peristiwa yang telah dialami Nabi dan para sahabat waktu itu. Ada yang menarik yaitu seruan Allah kepada Nabi dari ayat 1 sampai ayat 3 mulai dari seruan untuk bertakwa kemudian mengikuti atau mencontoh apa yang telah diwahyukan Allah kemudian anjuran untuk bertakwa lagi, ini menunjukkan adanya retorika bahasa yang begitu indah, bahwa anjuran Allah kepada Nabi untuk mencontoh dari apa yang diwahyukan itu sebagai upaya untuk bertakwa kepada Allah, sehingga Nabi jangan sampai mencontoh perilaku kaum kafir dan munafik yang bermaksud agar Nabi juga menghormati berhala-berhala mereka. Nabi sebagai manusia barangkali tidak mengetahui maksud terselubung mereka, namun Allah Dzat yang Maha Mengetahui yang lebih mengerti terhadap apa niat sesungguhnya dibalik sikap yang nampak tersebut.

\section{Pokok Kandungan Ayat Serta Korelasi Syarah Ayat Dengan Ayat Terkait}

Munâsabah (korelasi) dalam disiplin ilmu tafsir mempunyai arti sendiri yang secara bahasa berarti kedekatan. Secara istilah ialah segi-segi hubungan antara satu kalimat dengan kalimat yang lain dalam satu ayat, antara satu ayat dengan ayat lain. Pengetahuan tentang munasabah ini sangat bermanfaat dalam memahami keserasian antar makna, mukjizat al-Qur'an secara retorik, kejelasan keterangan, keteraturan susunan kalimatnya dan keindahan gaya bahasanya. Hal ini juga disebabkan karena sebuah kalimat terkadang merupakan penguat terhadap 
kalimat sebelumnya, seperti dalam ayat 2 al-Ahzab ini yang digunakan untuk memperkuat surat sebelumnya yaitu as-Sajdah ayat terakhir sebagai penjelasannya ialah awal surat al-Ahzab. (al-Khattan, $2001: 138$ )

Surat al-Ahzab ini merupakan kelanjutan dari firman Allah dalam ayat terakhir surat Sajdah ayat 30 yang berbunyi :

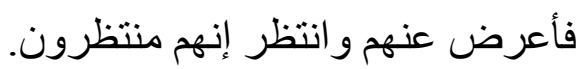

"Maka berpalinglah kamu dari mereka dan tunggulah, sesungguhnya mereka juga menunggu.”

Pada akhir surat Sajdah ini Allah memerintahkan Nabi untuk berpaling dari kaum musyrikin, tidak menghiraukan gangguan mereka sambil menanti putusan Allah. Hal itu disampaikan setelah menyatakan bahwa al-Qur'an adalah wahyu Ilahi yang bersumber dari Tuhan seru sekalian alam, dan agar beliau tetap konsisten, tidak meragukan wahyu Allah itu. Setelah uraian yang demikian dalam awal surat ini, Allah memulai dengan mengukuhkan kandungan akhir surat Sajdah tersebut. Hal ini terkait dengan firman Allah dalam surat al-Ahzab ayat 21 dan anNur ayat 54 yang berbunyi :

لقد كان لكم في رسول الله أسوة حسنة لمن كان يرجوا الله واليوم الآخر و ذكرا الله كثير.

"Sungguh telah ada pada diri Rasulullah itu suri teladan yang baik bagimu yaitu bagi orang yang mengharap rahmat Allah dan (kedatangan) hari kiamat dan yang banyak mengingat Allah.
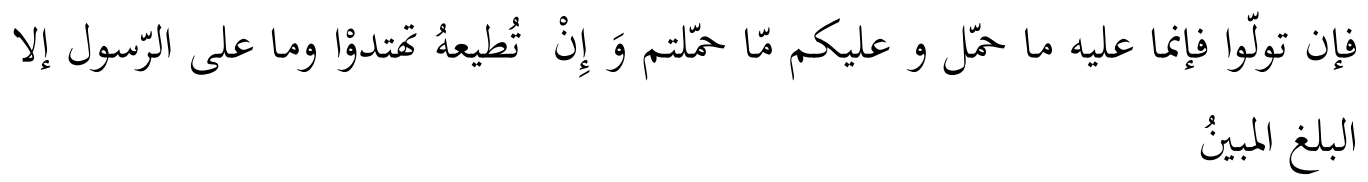

"Dan jika kamu berpaling maka sesungguhnya kewajiban Rasul itu adalah apa-apa yang dibebankan kepadanya, dan kewajiban kamu sekalian adalah semata-mata apa yang dibebankan kepadamu. Dan jika kamu taat kepadanya niscaya kamu akan mendapatkan petunjuk. Dan tidak lain kewajiban Rasul itu melainkan menyampaikan amanat Allah dengan terang"

Yang dimaksud dengan kandungan akhir surat as-Sajdah yang menjadi prinsip dasar dan selalu menjadi perhatian adalah bertaqwa kepada Allah, tidak 
patuh ajakan kaum kafir dan munafik serta mengikuti secara bersungguh-sungguh wahyu al-Qur'an yang diturunkan Allah itu. Sebagaimana dijelaskan dalam pembahasan asbabun nuzul diatas, bahwa turunnya ayat al-Ahzab ini adalah disebabkan ulah orang-orang kafir yang membuat jengkel Nabi. Perintah untuk mengikuti apa yang telah diwhyukan oleh Allah kepada Nabi dalam ayat ini, tidak terlepas dari perintah Allah pada ayat sebelumnya (al-Ahzab ayat 1) yakni perintah untuk bertaqwa kepada-Nya dan tidak mempedulikan urusan orang-orang kafir dan musyrik. Dengan adanya perintah untuk melaksanakan sesuatu maka pasti ada larangan terhadap kebalikannya. (Zuhaili, $1991: 21$ )

Setelah Allah memerintahkan untuk tidak mentaati dan mempedulikan urusan orang kafir dan musyrik, Allah kemudian memerintahkan untuk mengikuti apa yang telah difirman-Nya serta melaksanakan apa yang ada di dalamnya sebagai pedoman dalam menempuh jalan kehidupan, sebagai syariat yang lurus sebagai agama yang benar. Allah juga memerintahkan untuk berpegang teguh pada al-Qur'an. ( as-Shobuni : 511). Selain itu Allah juga menjelaskan pada ayat 21 dari surat al-Ahzab bahwa sesungguhnya setelah Allah sebagai Pemelihara (dalam ayat 3) dan anjuran untuk mencontoh dari apa yang telah diwahyukan Allah (dalam ayat 2), maka kita umatnya dianjurkan untuk mencontoh suri tauladan yang ada dalam diri Rasul sebagai uswatun hasanah. Sehingga setiap aspek kehidupan pada hakekatnya kita bisa meniru dan mencontoh keteladanan yang ada pada pribadi Rasul dan kita juga bisa mencontoh sifat-sifat yang dimiliki Allah yang diberikan kepada umatnya.

\section{Implikasi Ayat terhadap Pendidikan Terkait dengan Karakter Keteladanan}

Dari uraian diatas, dapat kita tarik kesimpulan bahwa dalam ayat ini ada beberapa hal yang dapat kita terapkan dalam dunia pendidikan dan lebih khusus pada metode pembelajaran, yaitu: pertama, adanya pendekatan keteladanan yang harus dilakukan oleh guru dalam ayat ini ada lafadz amar yang berarti "dan ikutilah”, jika demikian, maka harus ada yang diikuti. Dalam ayat ini yang harus diikuti adalah wahyu Ilahi. 
Jika konsep ini kita terapkan dalam dunia pendidikan maka yang disebut wahyu Ilahi adalah keteladanan sang pendidik yang menjelma dalam perilaku sehari-harinya, artinya dalam melakukan proses pembelajaran, tidak sepatutnyalah seorang guru itu hanya memberikan materi semata, tapi bagaimana pendidik itu dapat memberikan contoh yang baik kepada peserta didiknya sehingga walaupun tidak diperintah maka siswa itu dengan sendirinya akan mengikuti dan mencontoh sang guru yang mempunyai figure pribadi yang teladan dan performance yang baik sebagai cerminan bagi murid-muridnya.

Kedua, adanya hubungan yang mesra antara guru dan murid sehingga komunikasi yang berlangsung antara keduanya bisa berjalan secara berimbang. Bagaimanapun pola komunikasi sangatlah mempengaruhi efektifitas proses belajar mengajar. Ada kecenderungan dalam masyarakat bahwa pendidikan adalah di sekolah, di sekolah anak sudah cukup mendapatkan pendidikan, mulai dari pendidikan skill sampai pendidikan akhlak. Padahal pendidikan disekolah hanya satu bagian dari bentuk pendidikan, adanya ketergantungan orang tua dalam mendidik anak kepada sekolah berakibat pengabaian pendidikan di rumah dan masyarakat, padahal pendidikan di sekolah hendaknya bersesuaian dengan pendidikan di sekolah, paling tidak ada semacam kesamaan. Adalah mustahil pendidikan di sekolah dapat berhasil maksimal sedangkan pendidikan di rumah dan sekolah tidak mendukung.

Sebagai contoh anak di sekolah mendapat pelajaran salat dari guru agamanya, mulai dari persiapan hingga bacaan salat dan gerakan salat. Anak yang telah mendapatkan ilmu tentang salat diharuskan untuk mempraktekkannya dalam kehidupan sehari-hari. Ketika anak pulang dari sekolah, kemudian datang waktu salat, anak melihat ayah, ibu dan saudaranya tidak salat, bagaimana perasaan, pikiran anak tadi, Tentu akan timbul banyak anggapan dan praduga dan analisa, banyak jawaban dan komentar terhadap peristiwa tersebut. Mungkin anak akan enggan melaksanakan salat dengan alasan ayah, ibu dan saudaranya juga tidak salat jadi untuk salat. Atau ketika seorang guru menasehati anak didiknya untuk tidak merokok, kemudian pada waktu lain, anak didik melihat guru tersebut merokok. Bagaimana sikap siswa pada waktu itu, Bagaimana kesimpulan siswa, 
Jelas dia tidak akan mendengarkan nasehat yang keluar dari sang guru sebab ia telah menodai kepercayaan siswa yang besar terhadap gurunya. Sebab sikap dan tindakan yang kita perlihatkan pada siswa itulah yang berpengaruh besar terhadap keteladanan pada anak didik. Efektifitas keteladanan ini telah dicontohkan langsung oleh Rasul dalam berbagai hadits yang ditunjukkan bahwa ketika Rasul hendak mengajarkan shalat berjamaah, maka Rasul terlebih dahulu melakukan shalat jamah agar dicontoh dengan sahabat yang lain.

Masih banyak hal lain yang bisa menginspirasi kita dari diri Rasul karena Rasul memiliki akhlak yang baik, dengan demikian detiap tindakan dan ucapannya selalu ditiru dan dijadikan pedoman. Terlebih lagi karena Beliau tidak pernah menodai kepercayaan dari orang sekelilingnya. Adapun kata akhlak berasal dari bahasa Arab yaitu alkhulqu, al-khuluq yang mempunyai arti watak, tabiat, keberanian, atau agama. (Jauhari, 2006 : 88) Secara Istilah akhlak menurut Ibnu Maskawaih $(421 \mathrm{H})$ adalah

"suatu keadaan bagi jiwa yang mendorong ia melakukan tindakantindakan dari keadaan itu tanpa melalui pikiran dan pertimbangan. Keadaan ini terbagi dua, ada yang berasal dari tabiat aslinya, ada pula yang diperoleh dari kebiasaan yang berulang-ulang. Boleh jadi, pada mulanya tindakan itu melalui pikiran dan pertimbangan, kemudian dilakukan terus menerus, maka jadilah suatu bakat dan akhlak."

Akhlak yang diperlihatkan oleh guru, akan menjadi keteladanan dan lebih jauh lagi akan menjadi pembiasaan terhadap diri siswa. Indikasi bahwa akhlak dapat dipelajari dengan metode pembiasaan, meskipun pada awalnya anak didik menolak atau terpaksa melakukan suatu perbuatan/ akhlak yang baik, tetapi setelah lama dipraktekkan, secara terus-menerus dibiasakan akhirnya anak mendapatkan akhlak mulia. Al-Ghazali dalam Ihya Ulumuddin sebagaimana dikutip Muhammad Rabbi Muhammad Jauhari memberikan definisi akhlak sebagai"suatu ungkapan tentang keadaan pada jiwa bagian dalam yang melahirkan macam-macam tindakan dengan mudah, tanpa memerlukan pikiran dan pertimbangan terlebih dahulu" (Jauhari, 2006 : 88)

Dari dua defenisi di atas dapat dipahami bahwa akhlak bersumber dari dalam diri anak dan dapat juga berasal dari lingkungannya. Secara umum akhlak 
bersumber dari dua hal tersebut dapat berbentuk akhlak baik dan akhlak buruk, tergantung pembiasaannya, kalau anak membiasakan perilaku buruk, maka akan menjadi akhlak buruk bagi dirinya, sebaliknya anak membiasakan perbuatan baik, maka akan menjadi akhlak baik bagi dirinya.

Penjelasan tersebut mengindikasikan bahwa akhlak dapat dipelajari dan diinternalisasikan dalam diri seseorang melalui pendidikan, di antaranya dengan metode pembiasaan dan keteladanan. Dengan adanya kemungkinan diinternalisasikan nilai-nilai akhlak ke diri anak, memungkinkan pendidik melakukan pembinaan akhlak

Abdurrahman an-Nahlawi mengatakan metode pendidikan Islam sangat efektif dalam membina akhlak anak didik, bahkan tidak sekedar itu metode pendidikan Islam memberikan motivasi sehingga memungkinkan umat Islam mampu menerima petunjuk Allah. Menurut Abdurrahman an-Nahlawi macam metode pendidikan Islam adalah metode dialog, metode kisah Qurani dan Nabawi, metode perumpaan Qurani dan Nabawi, metode keteladanan, metode aplikasi dan pengamalan, metode ibrah dan nasihat serta metode targhib dan tarhib. (anNahlawi, 1996 : 204) Dari kutipan tersebut tergambar bahwa Islam mempunyai metode tepat untuk membentuk anak didik berakhlak mulia sesuai dengan ajaran Islam. dengan metode tersebut memungkinkan umat Islam/masyarakat Islam mengaplikasikannya dalam dunia pendidikan.

Muhammad bin Muhammad al-Hamd mengatakan pendidik itu mempunyai pengaruh besar dimata anak didiknya, apa yang dilihat dari gurunya akan ditirunya, karena murid akan meniru dan meneladani apa yang dilihat dari gurunya. (al-Hamd, 2002: 140) Dengan memperhatikan kutipan di atas dapat dipahami bahwa keteladanan mempunyai arti penting dalam mendidik akhlak anak, keteladanan menjad titik sentral dalam mendidik dan membina akhlak anak didik, kalau pendidik berakhlak baik ada kemungkinan anak didiknya juga berakhlak baik, karena murid meniru gurunya, sebaliknya kalau guru berakhlak buruk ada kemungkinan anak didiknya juga berakhlak buruk.

Dengan demikian keteladanan menjadi penting dalam pendidikan akhlak, keteladanan akan menjadi metode ampuh dalam membina akhlak anak. Mengenai 
hebatnya keteladanan Allah mengutus Rasul untuk menjadi teladan yang paling baik, Muhammad adalah teladan tertinggi sebagai panutan dalam rangka pembinaan akhlak mulai, sebagaimana terlihat pada penjelasan al-Ahzab 21 "Sesungguhnya Telah ada pada (diri) Rasulullah itu suri teladan yang baik bagimu (yaitu) bagi orang yang mengharap (rahmat) Allah dan (kedatangan) hari kiamat dan dia banyak menyebut Allah." Keteladanan sempurna, adalah keteladanan Muhammad Saw menjadi acuan bagi pendidik sebagai teladan utama, dilain pihak pendidik hendaknya berusaha meneladani Muhammad Saw sebagai teladannya, sehingga diharapkan anak didik mempunyai figur yang dapat dijadikan panutan.

\section{SIMPULAN}

Dari uraian diatas, dapat kita tarik kesimpulan bahwa dalam ayat ini ada beberapa hal yang dapat kita terapkan dalam dunia pendidikan dan lebih khusus pada metode pembelajaran, yaitu: pertama, adanya pendekatan keteladanan yang harus dilakukan oleh guru dalam ayat ini ada lafadz amar yang berarti "dan ikutilah”, jika demikian, maka harus ada yang diikuti. Dalam ayat ini yang harus diikuti adalah wahyu Ilahi. Jika konsep ini kita terapkan dalam dunia pendidikan maka yang disebut wahyu Ilahi adalah keteladanan sang pendidik yang menjelma dalam perilaku sehari-harinya. sehingga walaupun tidak diperintah maka siswa itu dengan sendirinya akan mengikuti dan mencontoh sang guru yang mempunyai figure pribadi yang teladan dan performance yang baik sebagai cerminan bagi murid-muridnya. Kedua, adanya hubungan yang mesra antara guru dan murid sehingga komunikasi yang berlangsung antara keduanya bisa berjalan secara berimbang.

Dengan kembali melihat surat al-Ahzab ayat 2, maka kajian analisis sintagmatis berupaya untuk menjabarkan ayat sebelum dan ayat sesudahnya. Adapun ayat 1 dan 2 dari surat al-Ahzab. Terkait dengan pernyataan tersebut, maka penulis juga merasa bahwa metode tafsir terhadap ayat 2 dari surat al-Ahzab ini ialah menggunakan metode semantic dengan pendekatan sintagmatis, yaitu suatu analisis yang memandang bahwa makna setiap kata pasti dipengaruhi oleh hubungannya secara linear dengan kata-kata disekelilingnya. Namun secara 
kinerja penulis lebih cenderung menggunakan analisis sintagmatik yang secara definitive suatu kata yang mempunyai hubungan dengan kata-kata yang berada didepan atau dibelakangnya. Penulis juga secara konseptual tetap mengacu pada penafsiran yang dilakukan oleh ulama terdahulu

\section{DAFTAR PUSTAKA}

al- Hamd, Muhammad bin Ibrahim. 2002. Maal Muallimin, Terj., Ahmad Syaikhu, Jakarta: Darul Haq.

al-Baidlowi, Nashiruddin. 1988. Anwaru at-Tanzil wa Isaru at-Ta'wil, Beirut : Dar al-Kitab al-Ilmiyah.

al-Fadl, Abu 'Ali Majma’ul Bayan. 1994. Juz VIII, Beirut : Dar al-Fikr, 1994.

al-Jazaini, Abu Bakar. 1994. Aisarut Tafasir,Juz IV, Madinah : Ulum wal Hikam.

al-Khattan, Manna' Khalil. 2001. Mabahis fi' Ulumil Qur'an, terj. Mudzakir AS. Bogor : Pustaka Litera Antar Nusa.

al-Syalhub, Fuad bin Abdul Azizi. 2005. Al-Muallim alAwwal shalallaahu alaihi Wa Sallam Qudwah Likulli Muallim wa Muallimah, ,terj. Abu Haekal, Jakarta: Zikrul Hakim.

An-Nahlawi, Abdurrahman. 1996. Ushulut Tarbiyah Islamiyah Wa Asalibiha fii Baiti wal Madrasati wal Mujtama’ Penerjemah. Shihabuddin, Jakarta: Gema Insani Press.

Ash-Shiddiqi, Hasbi dkk. 1971. Al-Qur'anl dan Terjemahnya, Khadim alHaramain asy-Syarifain.

as-Shobuni, Moh. Aly. Shafwatu at-Tafasir, Juz II, Makkah : Dar al-Kitab alIslamiyah.

as-Syaikholy, Abd. Wahid. 2001. Balaghoh Qur'an al-Karim. Oman : Maktabah Dandis.

Depag RI. 1999/2000. Petunjuk Pelaksanaan Proses Belajar Mengajar, Jakarta. 
Departemen Agama RI. 2006. Al-Quran dan terjemah dan Penjelasan Ayat Ahkam, Jakarta: Pena Pundi Aksara.

Jauhari, Muhammad Rabbi M. 2006. Akhlaquna, terj: Dadang Sobar Ali, Bandung: Pustaka Setia.

Katib, Abd. Karim. 1969. Tafsir Qur'an al-Karim,Juz II, Beirut : Dar al-Fikr.

Mubarok, A. Zaki. 2007. Pendekatan Strukturalisme Linguistik: dalam Tafsir alQur'an Kontemporer"ala” M. Shahrur, Yogyakarta : Elsaq Press.

Shihab, M. Quraish. 2002. Tafsir al-Misbah, Vol. III, Jakarta : Lentera Hati.

Syamsuddin, Sahiron. dkk., (ed). 2002. Studi Al-Qur'an Kontemporer: Wacana Baru Berbagai Metodologi Tafsir, Yogyakarta : Tiara Wacana. Dalam "Sahiron Syamsuddin, Metode Intratekstualitas Muhammad Shahrur dalam Penafsiran Al-Qur'an"

2003. Hermeneutika Al-Qur'an Mazhab Yogya, Yogyakarta : Islamika, 2003 dalam Abd. Mustaqim, Mempertimbangkan Metodologi Tafsir Muhammad Shahrur.

Zuhaili, Wahbah. 1991. Tafsir al-Munir, Beirut: Dar al-Fikr. 